\title{
DIFFERENCIÁLÓ KÍNÁLATMENEDZSMENT A TURIZMUSBAN- SENIOR SZÁLLODAI TERMÉKEK
}

\section{DIFFERENTIAL SUPPLY MANAGEMENT IN TOURISM - HOTEL PRODUCTS FOR SENIORS}

\author{
Kóródi Márta
}

Turizmus-Vendéglátás Tanszék, Gazdálkodási kar, Neumann János Egyetem, Magyarország

\author{
Kulcsszavak: \\ szállodamenedzsment \\ termékdifferenciálás \\ életkor szerinti szegmentáció \\ senior szegmens \\ termékfejlesztés \\ Keywords: \\ hotel management \\ hotel product differentiation \\ segmentation by ages in hotels \\ product development in hotels
}

\section{Összefoglalás}

A szállodai differenciáló termékstratégiák közé tartoznak a szegmensspecifikus kínálatot kialakító programok. A senior korosztály a szállodák számára mindig fontos volt. Szezonon kívül jelentenek keresletet, kiszámíthatóak, ismert igényekkel rendelkeznek, elégedettségük könnyen elérhetö. A kutatás arra a kérdésre keres választ, hogy élnek-e a szállodák a senior szegmens megnyerési lehetöségével, valamint milyen sajátosságokat mutatnak a számukra kiajánlott termékek. A dolgozat szekunder információkat feldolgozó részében a turisztikai marketing szakirodalom témához kapcsolódó részei a szállásadásra kerültek leszúkítésre, ezt követi a szegmens jellemző foglalási és tartózkodási szokásainak beazonosítása. A kínálat primer elemzésére megfigyeléssel került sor, a szállodák senior vendégkörnek szánt ajánlatainak összegyüjtésével és összehasonlításával.

\section{Abstract}

Differential hotel product strategies include segment-specific programs. The senior age group has always been important for hotels. They have the off-season demand, predictable and well-known needs, their satisfaction is easily accessible. The research is looking for the answer to the question of whether the hotels have the opportunity of acquire the senior segment and what are the special features of the products recommended for them. Parts related to the topic of tourism marketing literature have been reduced to the accommodation services in the secondary information processing section of this paper. This is followed by the identification of the segment's booking and residence habits. Primary analysis of supply will be by observation of collecting and comparing the hotels' offerings to senior guests.

\section{Bevezetés}

A szállodai szolgáltatások piacán a termék sajátosan értelmezendő, az adott vendég által előre összeválogatott, vagy csak az utazás befejezésével összeálló szolgáltatások körét jelenti. A szálláshelyszolgáltatási piacra is értelmezhetőek a marketing általános törvényszerűségei, jelenségei, mint ahogy a következtetéseket, módszereket a szakma fel is használja, alkalmazza. Egyik területe a 
szegmensspecifikus termékfejlesztés, ami kapcsolatban áll a terméken keresztül a marketing-mix érintett programjaival és stratégiáival, a piacszegmentálással, a fogyasztói szokásokkal, vagyis komplex marketing menedzsment feladat, amiben a fogyasztó orientáció is jól tükröződik.

Az igények a kor előrehaladtával is változnak, más jelent élményt a fiatal turistának és mást preferál az idősödő, tapasztalt utazó. A turisztikai keresletet tekintve öt generáció jelenik meg a piacon egyidőben. Ez egyrészt az eltérő generációs értékek ütközésével járhat, másrészt a piaci pozíciók megtartásához új típusú alkalmazkodást és proaktivitást igényel mind a fiatalabb, mind az idősebb korosztályok tekintetében. Az időseket a turisztikailag passzív, vagy visszafogott, főként gyógyszolgáltatásokat igénybe vevő vendégek sztereotípiájával illetik, holott a mobilitás időbeni kitolódásával árnyaltabb, összetettebb a fogyasztásszerkezetük.

A generációk szerinti fogyasztói magatartás kutatása a korosztályok sajátos kommunikációja miatt is indokolt, mind fogadóként, mind küldőként a stílus és az eszköz jellemző az egyes csoportokra, befolyásolásuk és kezelésük ennek megfelelően kell, hogy történjen. A tanulmány összegyưjti az előzetes ismereteket a senior korosztály általános és turisztikai érintettségével kapcsolatos jellemzőiről, következtetése pedig javaslatként szolgálhat a generáció specifikus termékfejlesztéssel foglalkozó, differenciáló termékstratégiát választó szállodák számára.

\section{Anyag és módszer}

\subsection{A téma elméleti háttere}

\subsubsection{A senior fogyasztói csoportok beazonosítása - szegmentálás}

A szállodapiac nem tekinthető homogénnek, jól szegmentálható, beazonosíthatóak az egyes időszakokban az eredményes múködést lehetővé tevő fogyasztói csoportok [5]. A kor a szociodemográfiai szegmentálási jellemzők között található meg, de a fogyasztók életstílusa is kapcsolódik a korosztályukhoz. A vizsgált, utazási tevékenységet folytató senior korosztály a nemzedék alapú osztályozásban a BB (Baby Boomer) generációhoz tartozik, bár egyes szerzők már egész fiatalon (40 év felett) seniornak titulálják az embereket. Az „elveszett nemzedék”, a „Rock' n' roll korszak gyermekei”, a „Baby boomerek” elnevezést kapta a generáció. A „próféták” címkét viselik, akik fiatal felnőttként a szellemi „ébredés” idején élnek, és ők lesznek a bölcs idősek, akik utat mutatnak a fiataloknak a következő „krízis” idején. Ennek a korosztálynak az idősebbjei már nyugdíjban vannak, a fiatalabbak még aktív keresők. Szemléletüket, magatartásukat, ideológiájukat nagyban meghatározta rendszerváltás. Egyrészük, a ma már nyugdíjasok, hozzá voltak szokva a kiszámítható jövőhöz, a fiatalabbak közül azonban sokan sokat veszítettek. Megszűntek az állami munkahelyek, a privatizált vállalatok új szemléletet, nyelvtudást, új munkakultúrát igényeltek, megtanulták az „önmenedzselést”[13].

A korlehatárolást az határozza meg, hogy akkortól tekinthető valaki a csoport tagjának, ha szembesül az új, idősödéssel jár gondokkal, mint az egészséghez kötődő veszteségélmény, a családhoz kötődő veszteségélmény és a munkához kötődő veszteségélmény [11]. Annak ellenére, hogy világjelenség a társadalmak elöregedése, problémás a szegmens elnevezése, az öregek, idősek, nyugdíjasok, ezüstkorúak a korosztály szinonimái. Ugyanakkor az „új öregek” (nyugdíjas kortól a hetvenes évekig) és az „öreg öregek” (hetven felettiek) megkülönböztetés [11] is kifejezi az igények, elvárások differenciáltságát, de a legárnyaltabb képet a gyerekek önállósodása, a nyugdíjazás, az egészségi állapot és a senior státusszal való identifikáció együttese adja[11]. Ezek szerint három senior fázis különíthető el:

- előseniorok: jellemzően aktív, magas jövedelmű, nagyszülő szerepet betöltő, újraorientálódó, a nyugdíjas szerepre előkészülő attitűddel rendelkezők

- fiatal seniorok: nyugdíjas, szúkülő jövedelmű, szociális változásokat, első egészségügyi panaszokat megélő, lassan identifikálódók

- idős seniorok: testi és szellemi változásokat megélők, növekvő függőségben élők, partnereket és barátokat elvesztők, identifikálódottak

A fogyasztói magatartást tekintve még hasznosabb megkülönböztetést szolgál az öntudatos, kritikus fiatal öregek, a felvilágosult, érdeklődő fiatal öregek és az aktív, rugalmas fiatal öregek csoportra bontás [11], akik a turizmusban valós szegmentumként vehetők számításba.

Törőcsik [11] az idősek szegmentálásának egy olyan, Karmasin (1995) által kialakított rendszerére hivatkozik, amelyben az egyik csoport turisztikai szempontból kiemelkedő, ők a „go 
goes” szegmens. „A go goes” azok, akik ugyan idősek, de nem érzik annak magukat, és meggyőződésük, hogy a biológiai kor nem azonos a szubjektíven megélt korral. Jellemző rájuk, hogy olyan szabadidős tevékenységet vállalnak, amelyeket mindig szerettek volna, de korábban esetleg nem volt rá alkalmuk, idejük. A pénzüket magukra költik, már nem mondanak le a gyerekek, az unokák javára. Nem maradnak le a fiatalabbaktól, utaznak, önmegvalósító törekvéseik vannak. Ezek nagyrészt azokat az idős vagy idősödő embereket jellemzik, akiknek megfelelő anyagi bázisuk van. Kevésbé érzik a jó körülményeket élvezők az életkor előrehaladtának következményeit, vagy jobban tudják azokat kompenzálni, mint szegényebb kortársaik.

Az életciklus modellek háztartásokat kategorizáló tipológiájában már idősebb párnak nevezik a kiürült fészek jellegű, gyerek nélküli háztartásokat, a szenior háztartást, a gyerek nélküli nyugdíjasokat és az idős egyedül élő háztartását. Általában a fogyasztói szegmens jellemzője, hogy milyen arányt képvisel a gondolkodásában a fogyasztás maximalizálása és az élmény maximalizálása. A senior szegmens nem polarizált, a fogyasztás is élményt jelenthet számára abban az esetben, ha aktív éveiben nem engedhette meg a turisztikai szolgáltatások igénybe vételét. Ugyanakkor a turisztikailag tapasztalt senior vendég élményekre vágyik, amitől a személyisége gazdagodását várja.

\subsubsection{A szegmentálás és a termék összefüggései, szállodaipari vonatkozásai}

A szállodák esetében is meghatározandó, hogy mely piacokon és milyen termékekkel jelenjenek meg. Ehhez a döntéshez szükséges a piac fó szegmentumainak beazonosítása az eltérő termékigény alapján, a célpiac kiválasztása és a terméktervezés, vagyis a piac megcélzása [9]. A szegmenseknek megfelelő termékek kialakításánál a termék minőségéről, jellemzőiről, a választékról, a design-ról, a márkázásról, a csomagolásról és a kapcsolódó szolgáltatástartalomról kell dönteni. A szegmensmarketingnek elsődlegesen a szállodák profilírozása felel meg, a szegletekhez a szegmentumok további bontásával lehet eljutni abból a célból, hogy ezeknek a kiscsoportoknak a kielégítetlen igényeire is tudjon a szálloda szolgáltatásokat ajánlani. A senior kínálat kialakítása ezen az elven alapul. A szegletmarketing általános előnyeit többé-kevésbé a seniorok esetében is lehet élvezni, fóként a speciális elosztási csatorna használatát és a speciális termék kínálata miatt potenciálisan kevés versenytárs szempontokat[9].

A senior piac kiválasztása egyrészt a szelektív szakosodás, másrészt a termékszakosodás ismérveit hordozza. Amennyiben a szálloda jól el tudja különíteni a senior kínálatát más vendégszegmentumoknak nyújtott ajánlataitól, akkor szelektív szakosodást folytat. Ha a meglévő szolgáltatásait kínálja a senioroknak sajátos kombinációban, akkor termékszakosodásról van szó. A piacszakosodás, vagyis a senior szegmens sokféle igényének teljes megfelelés és a termékinnováció az adott szegmens latens szükségletinek megfelelő alakítása csak elvétve jellemző. A szegmentum elérésének egyik módja a pozícionálás, vagyis a szegmens számára jól kommunikálható kínálati előnyök, a megkülönböztető, egyedi ismérvek meghatározása és előtérbe helyezése. De az idősebbek is nagyon heterogén csoportot jelentenek, nagyobb vásárlóerővel rendelkeznek és életmód-orientált szórakozási igénnyel bírnak [2].

A senior szegmensről gondolkodás a szállodai termék életciklus szakaszai közül az érettség időszakában fordul elő, amikor a piac növekedése lelassul, a piac kisebb szegmentumokra esik szét, fragmentálódik. Míg a korábbi szakaszban a seniorok a felnőtt vendégek csoportjába tartoztak, általános felnőtt szolgáltatásajánlatot kapnak, az érett piacon a hanyatlás időszakának elodázása érdekében és a szegmentum-szúkülés elkerülése miatt speciális kínálat létrehozása a kívánatos. A szolgáltatások pozícionálása esetén előtérbe kerülő tényezők egybecsengnek a senior korosztály által preferált jellemzőkkel: bizalom, biztonság, megbízhatóság [8].

\subsubsection{Az életkor szerinti szegmentáció általános jellemzói}

Az életkor minden életszakaszban érzékeny paraméter, a születési dátum csak egy tényező, hiszen a tényleges kor mellett figyelembe kell venni, hogy mennyinek érzi magát és mennyinek néz ki a fogyasztó. A fogyasztói típusok és az életkor összefüggései arra engednek következtetni, hogy a senior korosztály is különféle, a fiatalabbak a felső fogyasztói rétegben is átlagosan reprezentálják magukat, míg idősödve az alsóbb fogyasztói típusok kerülnek átlagos reprezentáltság fölé. Ez azonban nem jelenti azt, hogy ne lenne a korcsoportban olyan fizetőképes kereslet, amire a szállodák a holtidőszakok töltése érdekében ne építhetnének. Főként azért is, mert a szálloda ezt a piaci csoportot hatékonyan ki tudja szolgálni szezonon kívül. 
A seniorok, mint fogyasztók elvárásainak egy része nem életkor specifikus, de letisztultan az idősöknél jelentkezik természetes igényként. Ilyen az egyszerűség szeretete, a felesleges dolgok elutasítása, a kényelem igénye, az eredeti, hiteles dolgok megbecsülése, a bizalom fontossága. Értékelt tulajdonságok még többek között a természetesség, a minőség, a melegség, a barátságosság, a kényelem, a puhaság, a nem irritáló alapanyagok, a szép tárgyak, anyagok, finom illatok, ízek, a megértés, a személyre szabottság, az észrevehetetlen, diszkrét segítség [11]. A tulajdonságok alapján már körvonalazható a senior szállodai termék. A pozicionáláshoz azonban még ismerni kell a senior turista utazási döntéseit meghatározó további kritériumokat, mint a szolgáltatás terméktulajdonságait, mint az elhelyezkedés, esztétika, a szimbolikus termékjellemzőket, mint az igényesség, a gazdaságosság tekintetében az ajánlat összetevőit, árát, a fogyasztói csoportot, például a fogyatékkal élők miatt, vagy az értékesítés helyét, az online vagy a valós utazási iroda választást [7].

\subsubsection{Termékfejlesztés - termékdifferenciálás}

A turizmus iránti leggyakoribb szükségletek a stresszmentes kikapcsolódás, az intenzív átélés, a kapcsolatteremtés és az aktivitás iránti igény [10]. Ezek a motivációs tényezők szinte maradéktalanul megjelennek a senior turisták utazási döntéseiben. A rekreációs tényezők között található a pihenés, a szabadidő élvezete, kaland és romantika-keresés. A kulturális tényezőcsoportból szerepet játszik a döntésben a más kultúrák, emberek, hobbik, életmódok megismerése, különleges helyek és események meglátogatása. Az etnikai motiváció-csoportba a szülőföldre visszatérés, az ismerősök által látott helyek felkeresése és az egyes népcsoportok szokásainak megismerése tartozik.

A termékfejlesztés új termékek és szolgáltatások ötletteremtésének és sikeres megvalósításának folyamata az értékesítés növelése és ezen keresztül a többletprofit elérése érdekében. A folyamat első lépcsője az új ötletek megtalálása, felvetése, aminek két forrása van, a piaci igény vagy a müszaki ötlet, technológiai nyomás. A piaci igényből való kiindulásnál piaci szívóhatás (demand pull) jelentkezik. A piac szükségleteinek felismerése a piaci jelzéseken keresztül valósul meg. Ilyen jelzésének tekinthető a fogyasztói kereslet, a javak és tényezők árviszonyai, mennyisége [3]. A turizmusban jellemzően ez jelenik meg. A teljes turisztikai termék: komplex termék, amely magában foglalja a desztinációt, és a turisztikai szolgáltatások megfogható illetve megfoghatatlan elemeit, valamint az ott zajló tevékenységet [5]. Marketing szempontból a turisztikai termékfejlesztés a 4. típusú termékfejlesztésnek felel meg [12], miszerint a termékvariációk létrehozásánál a termékek különböző változatait fejlesztik ki a differenciált igények kielégítése, vagy éppen az igények differenciálása érdekében.

\subsection{A vizsgált sokaság és a vizsgálat módszere}

A senior szállodai termékek feltárása megfigyeléssel történt. Az online utazási irodák kínálata alapján, illetve közvetlenül a szállodák honlapjáról kerültek kiválasztásra olyan ajánlatok, amelyekben valamilyen módon megjelenik az, hogy a senior szegmensnek pozícionálták a terméket. A vizsgálatban három magyar utazási portál érintett ajánlatai teljes körüen elemzésre kerültek (www.szallas.hu, www.szallasvadasz.hu, www.utisugo.hu). A duplumoktól megtisztítva 56 ajánlatból áll az adatbázis ${ }^{1}$, amit kiegészített két külföldi senior utazási portál az ajánlataival az összehasonlítás érdekében. Az általános ajánlatokon kívül legalább egy termékelemnek szegmensspecifikusnak kell lennie, hogy bizalommal válassza a korosztály. Az ajánlatok értékelése 1-5 skálán történt a senior

\footnotetext{
${ }^{1}$ A vizsgálatba bevont szállodák: Aqua Hotel Kistelek, Aranyhomok Business és Wellness Hotel, Balneo Hitel Zsori Thermal \&Wellness Mezőkövesd, Bodrogi Kúria, Inárcs, Corso Boutique Hotel Gyula, Elizabeth Hotel Gyula, Erzsébet Hotel Hévíz, Főnix Medical Wellness Resort, Nógrádgárdony, Fries Kastély Szálloda Simontornya, Gosztola Gyöngye Hotel, Gosztola, Hajnal Hotel Gyógyszálloda Mezőkövesd, Hasik Hotel, Döbrönte, Hotel Anna, Mátrafüred, Hotel Bellevue, Esztergom, Hotel Corvus Aqua, Gyopárosfürdő, Hotel Délibáb, Hajdúszoboszló, Hotel Eger Park, Eger, Hotel Három Gúnár, Kecskemét, Hotel Kapitány Sümeg, Hotel Konferencia, Győr, Hotel Lővér, Sopron, Hotel Magyar Király, Székesfehérvár, Hotel Nagyerdő, Debrecen, Hotel Napsugár, Hévíz, Hotel Narád Park, Mátraszentimre, Hotel Négy Évszak Hajdúszoboszló, Hotel Ovit, Keszthely, Hotel Platán, Sárvár, Hotel Rudolf Hajdúszoboszló, Hotel Sopron, Sopron, Hotel Szieszta, Sopron, Hotel Vital Zalakaros, Hotel Wolf, Sárvár, Hotel Xavin Restaurant Wellness, Harkány, Hunguest Hotel Bál Resort, Balatonalmádi, Karádi Boutique Hotel Hajdúszoboszló, Károlyi-Kastély Hotel, Fehérvárcsurgó, Kincsem Wellness Hotel Kisbér, La Contessa Kastélyhotel, Szilvásvárad, Laroba Wellness \& Tréning Hotel Alsóörs, Liget Wellness és Konferencia Hotel Szarvas, Misefa Kastély, Misefa, Öreg-tó Hotel Tata, Panoráma Wellness Hotel, Békéscsaba, Pilvax Hotel, Kalocsa, Portobello Hotel Esztergom, Royal Club Hotel Visegrád, Silvanus Konferencia és Sport Hotel, Visegrád, Szarvaskút Wellness Hotel és Kemencés Étterem Zirc, Thermál Hotel Balance, Lenti, Thermal Hotel Harkány, Thermal Hotel Visegrád, Thermál Park Hotel Egerszalók, Tisza Hotel Szeged, Viktória Hotel Sárvár, Viktória Wellness Hotel Nagyatád
} 
kínálati elemszám alapján. Egy a skálaértéke annak a kínálatnak, amelyik csak a csomag elnevezésében utal a korcsoportra, de nincs speciális szabadidő eltöltési lehetőség számukra. Ez csak árdifferenciálást jelenthet az alacsony keresletű időszakokban, ami nem a termékfejlesztés része. Kettő a skálaérték, ha egy speciális kínálati elem található. A hármas és négyes skálaérték rendre kettő vagy három elem meglétét jelenti. Amennyiben ennél több található, ötös értéket kapott. A jellemzők között a minősítés is megjelent, mert feltételezhető, hogy a magasabb kategóriákban a szegmenseknek megfelelőbb termékfejlesztés folyik, vagyis differenciáltabb a kínálat.

\section{Eredmények}

Bár a szállodai minősítés jelenleg nem kötelező feltétele a minősítésnek, a szállodák többsége használja a kategória megjelölést. A vizsgált ajánlatokat nyújtó szállodák négycsillag szuperior, négycsillagos, háromcsillag szuperior, háromcsillagos és kétcsillagos besorolásúak voltak, valamint minősítés nélküli szállodák is szép számmal akadtak az ajánlattevők között. A minősítés nélküliség nem jelent rossz minőségü szolgáltatást, csupán s szálloda azon döntését jelzi, hogy nem minősíttette magát a Hotelstars Union követelményrendszere alapján, ami egyben jelentős ráfordítást is jelent a szálloda számára. A minta eszerinti megoszlását az 1.ábra mutatja.

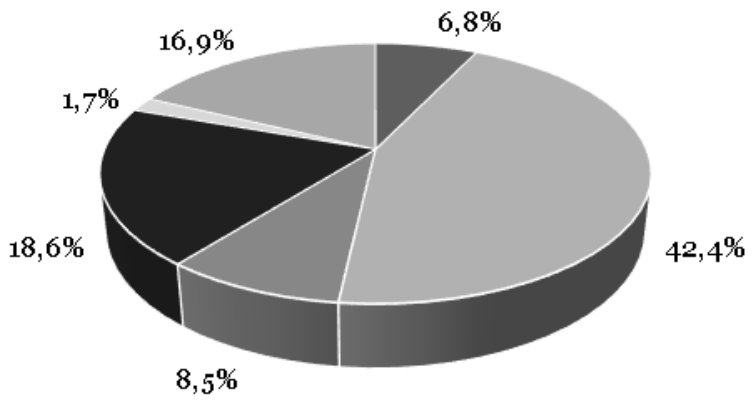

$\begin{array}{lll}\text { - négycsillag superior } & \text { ¿négycsillag } & \text { ¿háromcsillag superior } \\ \text { - háromesillag } & \text { ¿kétcsillag } & \text { ¿minősítés nélküli }\end{array}$

\section{1.ábra Az adatbázis szállodáinak megoszlása minősítési kategóriánként (n=56)}

Az adatbázisban szereplő szállodák mindegyike vidéki, vélhetően a fővárosi szállodáknak nincsenek töltési problémáik a szezonidőszak elmúltával, még kedvezményes ajánlatot sem készítenek, nemhogy szegmensspecifikus terméket alakítsanak ki. A szálloda elnevezésében megjelenő profilok a wellness és a resort, de kevés gyógyprofil és konferenciaprofil is található. A gyógyprofilú szállodák általában nem ajánlanak külön a senioroknak, hiszen fő szegmensük a korosztály, ezek a szállodák tartózkodási idő alapján differenciálnak. A környezeti adottságok vegyesek, került be városi szálloda és erdei hotel is a felmérésbe.

A senior csomagok elnevezése egyhangú, a nyugdíjas és a senior kifejezések váltakoznak a csomag, akció, ajánlat, napok, pihenés főnevekkel. Megjelenik az arany és az ezüst is, mint jelző az elnevezésekben. Több szálloda használja a „nemcsak a húszéveseké a világ” régi sláger népszerü sorát, illetve az örökifjak, aranyifjak, aranykorúak, szépkorúak hívószavak is megtalálhatóak.

Számos esetben az elhatároló kor is szerepel a csomag fantázianevében (pl.: Kényelmesen 50 felett), vagy finom utalás a korra az „Egy tisztes őszes halánték” nevű ajánlat. Az unokákkal együtt tartózkodásra buzdít a Nyugdíjas és nagyszülő ajánlat elnevezés. Két szálloda „idilli nyugdíjas hétköznapok” csomagnevet alkotott, az egyik legjobb azonban az „Old timer akció”. Különleges ajánlatát a csomag nevében is közli az Öreg-Tó Hotel, Elektromos mopeddel Tatán elnevezést adva. Jól sikerült a „Senior élménycsomag az egészségért” elnevezés, főként azért, mert a tartalmával is harmonizál.

$\mathrm{Az}$ ajánlatok minősítése a seniorspecifikus kínálati elemek számától függött, az egyes minősítési kategóriák gyakoriságát a 2. ábra mutatja. Megállapítható, hogy a szállodák többsége az árdifferenciálás módszerével él és árkedvezményeket ad a senior vendégkörnek bizonyos, kereslethiányos időszakokban, de csak az árérzékenységet veszi figyelembe, mint 
szegmensspecifikus jellemzőt. A szabadidő eltöltését nem menedzseli differenciáltan. Csaknem a felét adja ez a stratégia a mintának.

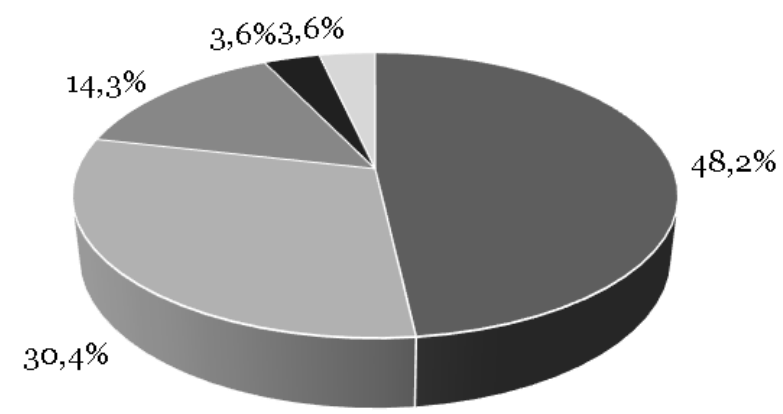

$$
\begin{aligned}
& \text { - csak a nevében szerepel az utalás ॠ egy senior kínálati elem } \\
& \text { - } \text { - két senior kínálati elem - három senior kínálati elem } \\
& \text { - háromnál több kínálati elem }
\end{aligned}
$$

\section{2. ábra Az adatbázis szállodáinak megoszlása a senior kínálat alapján (n=56)}

A skálaértékek átlaga a teljes mintában kettő körül volt várható, mivel a minta fele egyes értékű, a másik fele legalább kettes, ténylegesen 1,84 lett. Az a hipotézis, hogy a magasabb kategóriájú szállodák jobban kommunikálják a szegmensnek megfelelő kínálatot az átlag kategóriánkénti megbontásával igazolható (3. ábra).

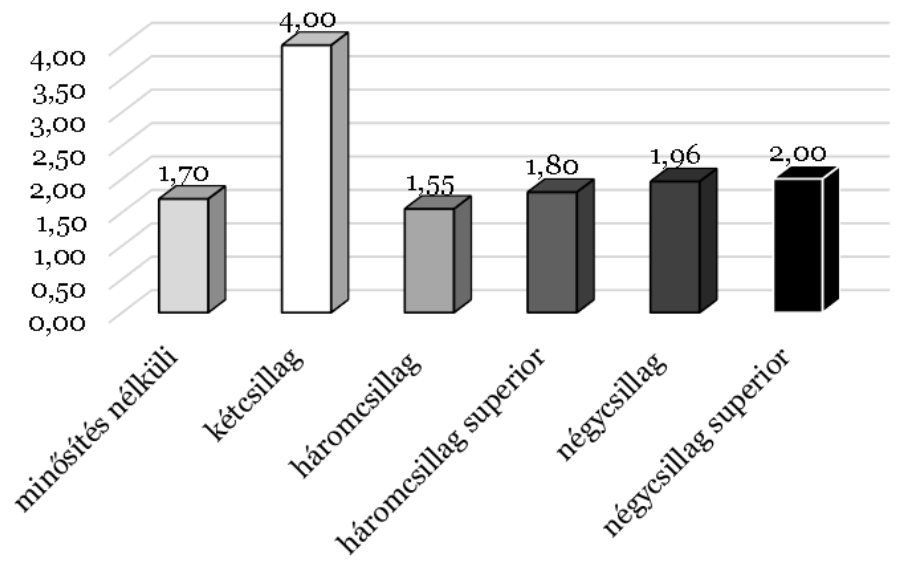

\section{3. ábra A kategóriák seniorspecifikus termékelem előfordulásának átlagai}

A kereszttáblás elemzés is mutatja, hogy a hipotézis igazolódott, a kétcsillagos kategóriát képviselő egy előfordulástól eltekintve a többi kategóriában az elismert minőség javulásával a szegmensnek megfelelőbb ajánlatot alakítottak ki, vagyis pozitív az összefüggés a minősítési kategorizálás és a szegmensspecifikus termékfejlesztés között a mintában.

Az ajánlatok részletes áttekintése után az alábbi, többször előforduló elemekkel jellemezhető a senior termékek:

hétköznapokra vonatkoznak, több éjszakás a kiajánlás, a szállodának a vasárnapi érkezés és a csütörtöki távozás a legkedvezőbb. Hétvégi foglalás esetén felárat határoznak meg, vagy kivételes napokat listáznak (ünnepek, tematikus hétvégék), vagy az igénybevehetőséget naptárban jelölik ki

- $\quad$ ajánlanak gyermekkedvezményeket bízva abban, hogy az unokákkal érkező nagyszülőket is meg tudják nyerni

az ajánlatok egyik kikötése, hogy szobánként minimum egy nyugdíjasnak, vagy a korkritériumot teljesítőnek foglalnia kell, de egy kedvezményezett csak egy szobát foglalhat. 
- a fakultatív programokat említik, vagy részletesen fel is sorolják, az árakat azonban nem, vagy hiányosan tüntetik fel, ami bizalmatlanságot eredményezhet.

általános a félpanziós ellátás, több esetben azonban a vendég választhat, hogy a reggelin kívüli második fóétkezés az ebéd, vagy a vacsora lesz-e. Ez különösen kedvező az idősek számára a késői étkezés elkerülése érdekében. Ugyanakkor a bőséges reggelit követően későn éheznek meg a vendégek, de estig nem bírják ki, ezért egyes szállodák bevezették a levesebédet.

- $\quad$ az ajándék italok és ételek sora bőséges, egy alkalommal, vagy akár minden nap kávé és teafogyasztás, süteménybekészítés, gyümölcsbekészítés tartozhat a csomagba. A délutáni teát a játékokkal (kártyajáték, társasjáték) kötik össze, vagy a könyvtárban szolgálják fel, közösségi programként animálják.

kóstolókkal lehet edzeni a gasztronómiai nyitottságot, pl. az ősz alkalmas a mézkóstolásra, de a szállodai séfek a vacsora büféasztalon bemutathatnak egy-egy különleges alapanyagot vagy technológiát amellett, hogy a vendégek a hagyományos ételeket is megtalálják

a háziállatok sem jelenthetnek akadályt, a tarifák megjelennek a csomagárak mellett

a programok a korosztály életritmusához alkalmazkodnak, türelmesek a manufaktúra látogatáshoz, amin a fiatalok csak gyorsan átrohannak. Az ingyenes múzeumbelépőt is jól fogadják, szívesen sétálnak arborétumban, tóparton, parkban, a kastélylátogatásokat, vezetett városnézéseket is szeretik, szervezhetők erdei kirándulások.

a fizikailag aktív seniorok számára a kerékpározás (kerékpárbérlés a csomagban ingyenes) jó időtöltés, útvonaltervvel kell őket ellátni. Szívesen kipróbálják a nordic walkingot. A senior torna is szerepelhet a grátisz programok között szabadtéri, vízi vagy termi környezetben. Különleges senior sportajánlat a smovey rezgőgyürüs gyakorlatok kipróbálása, amit különlegessége miatt meg fognak emlegetni, igazán élményszerű mozgást biztosít.

az egészségügyi állapotfelmérés a gyógy - és wellness szállodák tipikus inclusive ajánlata. A csomag időtartama alatt egy gyógymasszázst is többnyire tartalmaz a program, de ezt egyes helyeken hidromasszázs ágyhasználat helyettesíti. Hangsúlyozott a kommunikálása a fürdőbelépőknek (vendégéjszaka számmal megegyező alkalom), a fürdőköntös, törülközők és más kiegészítők rendelkezésre bocsátásának.

a vendégek különböző igényeihez alkalmazkodást a választható szolgáltatások felajánlásának rendszere biztosítja, például egy szolgáltatást grátisz választhat a pedikưr, az egy órás hintózás vagy a masszázsok közül. Kaphat kuponokat is a vendég, amikből egy tartózkodás alatt korlátozottan válthat be (pl. kozmetikai kezelés), így ösztönöz a visszatérésre. Az esti szórakozást élőzene kíséri, de szervezhetnek retro disco-t is.

A külföldi szállodai senior ajánlatok eltérnek a hazai összeállításoktól. Külföldön, egyrészt külön a seniorokat utaztató utazási irodák (hagyományos és online is) jöttek létre, a teljes tartózkodási időt menedzselik, átvéve ezt a szerepet a szállodáktól. Az árelőny a kommunikációjuk alapja és komplett utakat szerveznek, sok a luxus körutazás, hajóut. Másrészt a tehetősebb senioroknak gyakori az all inclusive ellátás, hogy tényleg ne kelljen semmivel sem foglalkozniuk, csak üdülni. A szállodák esetében ezért nagyon nehéz senior programot találni. A BabyBoomerTrips honlapján komplett all inclusive ajánlatok, szállodai termékek, hajóutak, „bakancslista” ajánlatok és last minute ajánlatok szerepelnek tényleges differenciált kínálatot megjelenítve.

\section{Következtetések}

A szállodák az egyenletes töltésre törekednek, a csúcs és a holt időszakok kiegyenlítésére úgy, hogy a csúcsidőszakokban maximalizálják a profitot, a holtidőszakokban pedig elérjenek annyi bevételt, ami a szálloda fenntartásának állandó költségeit és a vendégáramlással, a vendég fogyasztással járó változó költségeket fedezze. Ezért hajlandóak és kényszerülnek kedvezményes árakat alkalmazni. A senior ajánlatok sajátossága, hogy egy árérzékenynek titulált szegmesnek engedményes áron kínálnak szolgáltatásokat. Mindezt azonban egyrészt megtévesztő, mert a szegmens - azt a kínálatban néven nevezve - a sajátos szabadidő eltöltési lehetőségeket várja a 
szállodától és indifferens kínálattal szembesül (fitness terem), valamint ettől a diszharmóniától leértékelt szegmentumnak tartja magát.

Megoldást a két stratégia együttes alkalmazása jelenthetne, legalább egy, olyan senior program beiktatása, amelyik éreztetné a vendéggel, hogy számára fejlesztették a terméket, törődik vele a szálloda, ugyanakkor nem járna jelentős többletköltséggel a szálloda számára. Többnyire ez animációval megoldható és a vendégek kapcsolatteremtési igénye is egyben kielégíthető. Az árengedmények a fogyasztást ösztönző funkciót ekkor is betölthetnék, a senior programok az egyszerű kedvezményes árnál szélesebb szegmens számára lennének vonzók és élménytartalmuk is gazdagabb lenne. Valamint előnyt jelenthetne az is, hogy ez a lelkileg érzékeny szegmens nem érezné magát másodrendünek, megtürtnek.

Árnyalhatná a megoldást a magasabb fizetőképességü (prémium) senior réteg számára hosszabb, tartalmasabb, több fakultatív programot magában foglaló csomag fejlesztése. A senior korosztály törzsvendéggé válását ösztönözné, ha a kényelmen kívül a bőséges választékból maradnának olyan vonzó programelemek, amiket érdemes lenne visszatérve igénybe venni. Mivel különösen barátkozóak a seniorok, az ismerősökkel visszatérésre is ösztönözhetőek lennének. Stabil senior törzsvendégkörrel a szálloda megfelelő töltést tud biztosítani a gyenge keresletes időszakokban is.

\section{Köszönetnyilvánítás}

Köszönettel tartozok a kutatás támogatásáért, amely az EFOP-3.6.1-16-2016-00006 „A kutatási potenciál fejlesztése és bővítése a Neumann János Egyetemen” pályázat keretében valósult meg. A kutatás előkészítésében résztvevő tanszéki demonstrátort, Jenei Bettinát, valamint Czégény Lívia és Csató Laura hallgatókat is köszönet illeti. A projekt a Magyar Állam és az Európai Unió támogatásával, az Európai Szociális Alap társfinanszírozásával, a Széchenyi 2020 program keretében valósul meg.

\section{Irodalomjegyzék}

[1] Baby Boom generáció. Online elérés: http://multkutato.hu/baby-boom-generacio/ Letöltés időpontja: 2018. november 24.

[2] Elisa Alén, Nieves Losada \& Pablo de Carlos (2017) Profiling the segments of senior tourists throughout motivation and travel characteristics, Current Issues in Tourism, 20:14, 1454-1469, DOI: 10.1080/13683500.2015.1007927 Online elérés: https://www.tandfonline.com/doi/abs/10.1080/13683500.2015.1007927, Letöltés dátuma: 2018.11.24

[3] Józsa László (2006) Marketing. Veszprémi Egyetemi Kiadó.

[4] Kóródi Márta (2018) Generációspecifikus kínálatmendzsment a turizmusban. In: Economica . IX. évf. vol. (3). Online elérés: https://gk.uni-neumann.hu/uj-eco-9-3, Leöltés időpontja: 2018. november 15.

[5] Kovács Péter (2016): Turizmusmarketing elméletben és gyakorlatban. Kodolányi János Főiskola, Székesfehérvár

[6] Lengyel M. (2002) A turizmus általános elmélete-I. Budapest: Heller Farkas Gazdasági és Turisztikai Szolgáltatások Főiskolája, 65-69., 108, 187.p.

[7] Lőrincz Katalin, Sulyok Judit (szerk.) (2017) Turizmusmarketing. Akadémiai Kiadó, Budapest, Online elérés: https://shibboleth.mersz.org/?xmlazonosito=dj277tm_o_p1\#dj277tm_o_p1, Letöltés időpontja: 2018.11.08.

[8] Rekettye Gábor, Hetesi Erzsébet (2017) Kínálatmenedzsment. Akadémiai Kiadó,Budapest. Online elérés: https://shibboleth.mersz.org/?xmlazonosito=dj228km_116_p1\#dj228km_116_p1 Letöltve: 2018.11.11.

[9] Szigeti Orsolya, Szakály Zoltán (2011) Marketing, Kaposvári Egyetem, Kaposvár. Online elérés: https://www.tankonyvtar.hu/hu/tartalom/tamop425/o059_marketing_hu/cho6so2.htm, Letöltés időpontja: 2018.11.08.

[10] Tasnádi J. (1998): A turizmus rendszere. Szolnok: KGF, 106-307.p.

[11] Törőcsik Mária (2016) Fogyasztói magatartás Akadémiai Kiadó, Budapest, https://shibboleth.mersz.org/?xmlazonosito=dj72fm_76_p1\#dj72fm_76_p1 Letöltés időpontja: 2018.11.11.

[12] Veres Zoltán-Szilágyi Zoltán (2007): A marketing alapjai, A Budapesti Gazdasági Főiskola megbízásából kiadta a Perfekt Gazdasági Tanácsadó, Oktató és Kiadó Részvénytársaság

[13] Zombainé Tarnótzky Krisztina (2015) Generációk összehasonlítása, különös tekintettel a Z generáció és tanáraik között fellelhető különbségekre Online elérés: http://dolgozattar.repozitorium.bgf.hu/2395/1/Zombaine_Szakdolgozat.pdf Letöltés időpontja: 2018. november 24. 